\title{
Research of College English Teaching based on Employment-oriented Consideration
}

\author{
Yao Liu
}

Linyi University, Linyi, Shandong, 276400

\section{Keywords: Employment-oriented, College English, Teaching Method}

\begin{abstract}
As we all know, employment is the fundamental goal of vocational education, employment-oriented international education is the trend. How to fundamentally solve the problem of college students employment difficult, on the one hand the government needs to actively consider the response, on the other hand, colleges and universities should also deepen the education and teaching reform, the quality of personnel training in the first place, adhere to market-oriented, quality of survival, To the characteristics of development, to the employer satisfaction as the standard, continue to adapt to the changing employment situation, the formation of enrollment, training, employment and good mechanism.
\end{abstract}

\section{Introduction}

From the second half of the 20th century, the beginning of the 20th century, college students began to become a problem, year after year by the community hot. More than a decade later, the problem did not ease, but the plot more and more heavy. In recent years, the media frequently reported that college students will be full of people suffering from the scene, and thousands of people competing for a job case, to the people left a deep impression. Especially in recent years, with the deepening of the financial crisis, the employment situation of college students is more tight.

Public English teaching reform is also facing great challenges. At present, China's employers not only require candidates for English proficiency in college students, but also require them to combine the business ability of English with the candidates to better serve the international market. However, at present our college English education system can not reflect and meet the needs of society and the market, but also can not adapt to the globalization process of the employer's multi-level demand for English talents, cultivated college students in English combat ability and market and There is a huge gap between the needs of society. Therefore, the English proficiency of college students has directly affected the employment competitiveness of college students, which directly affect their future development space. This has brought great impact and pressure to public English teaching. It is required that public English teaching should form and highlight their own characteristics , According to vocational skills training and employment-oriented principles, and constantly strengthen the curriculum of basic construction, improve the overall level of teaching and graduate employment competitiveness.

\section{The Current Situation of College English Teaching and the Problems}

In the college English teaching in China, the focus of the training mode and the purpose of students' learning are often related to the teaching requirements of the Department of Education and the academic orientation of the university. The content of the teaching of English teachers in colleges 
and universities mostly focuses on the inculcation of written knowledge and the purpose of students studying English courses is also focused on trying to obtain various certificates through various exams. So that English as an exchange tool does not effectively play its essential role. The result is that many students who have passed the college English four-six exam are still difficult to meet in situations where they need to communicate in English Easy to deal with even unable to deal with. It is even more difficult to express your expertise in English or to consult the relevant English literature. Therefore, we conclude that the traditional college English teaching model, which is oriented by the examination, is the shackles of the practical communication between students in English and the access to information - English oral translation and communication - written translation. The vast majority of students still use rote learning methods. In addition, the old teaching idea of college teachers is also an important factor affecting the lack of practical links in teaching. College teachers are limited by traditional teaching models. They often lack the sense of innovation in the teaching process, and blindly pursue test scores, the pursuit of overweight rate. But often overlooked the cultivation of students in the actual use of English ability, resulting in students in English practice ability becomes more and more weak. And even learn the useless phenomenon.

In college English teaching, teaching hours is still one of the important reasons for restricting the development of students' English practical ability. Here to Qiqihar Medical College English teaching hours, for example, our college English teaching average teaching hours for each semester, hours, and in these teaching hours, the need to solve the students reading and writing, listening and speaking, comprehensive training and other issues The Due to limited teaching time, teachers and students often overlook the important part of English literacy. And some teachers to textbooks for college English reading and writing material, often more limited. Different from other institutions of higher learning, the English teaching part of English teaching in our school has inherent school, which can enhance students' attention to English listening comprehension. However, most of these listening training are often for the English level examination format format, almost few such as news, lectures, video and other resources, listening training. And as the practice of English practice in the oral subject training is often because of the teaching progress $\$$ test-oriented and other factors are weakened or even ignored. It can be seen that the overall uniform college English teaching material is difficult to make the students' English practical ability to be personalized and comprehensive training. Because the teaching materials of college English are generally the national planning materials, which greatly improves the students' English knowledge learning system and integrity, but the teaching materials are often humanistic education or cultural theme occupies a large proportion, And the practice of English teaching content, especially in line with the characteristics of students of the practice of teaching material is very lacking, and this problem is difficult to update the way through the teaching materials completely resolved, because the actual level of student English by its regional and professional The difference between the great impact of uniform requirements of the test-type textbooks difficult to meet the individual needs of students.

\section{Employment-Oriented, Deepening the Reform of Public English Teaching}

English is not solid foundation, the level of uneven, poor learning effect, so English teaching must pay attention to the basic knowledge of students learning. Public English teaching should proceed from the reality, step by step guide students, from the language to improve the ability to strengthen the basic knowledge of language learning and consolidation, such as voice, vocabulary, sentence and so on. However, pay attention to the basic knowledge of students learning, can not ignore the listening and speaking skills training and writing application ability. Second, there must be a sense 
of advanced job competition. Teachers in the classroom teaching to use the content of the text itself to teach new ideas to students, the book learning and social development closely linked. Students should also consciously combine these knowledge and information with the professional study, choose to learn "useful" knowledge, so that time to update the concept of understanding, to keep abreast of their future career areas. Finally, the employment of students as the center, improve the competitiveness of employment. In the emphasis on English knowledge learning and basic skills training, highlight the listening, speaking, reading, writing, translation of the comprehensive application of English ability to express at the same time, to form a multi-faceted, three-dimensional English learning environment and atmosphere, to carry out a wealth of English activities inside and outside. And in the teaching of purpose, there are plans to run through the employment before the English job skills and health psychological guidance.

As the organizer of teaching activities, public English teachers should first combine the characteristics of the students of this school, through practice to study the characteristics of education and teaching methods, at the same time to change in the traditional teaching of the role, status, by the knowledge of the transfer, The speaker becomes a mentor and trainer of practical ability, highlighting the student's dominant position in teaching. English teachers in the study of teaching methods at the same time, we must strengthen the professional knowledge of learning and understanding, whether it is teaching, or scientific research, should be closely linked with the college set up professional, combined, and strive to expand the field of knowledge, , To the "double teacher" type of teacher direction.

Although public English is a common foundation course for each profession, there is a difference in the construction of English knowledge and competency structure of the training objectives and professionals. Therefore, the public English teachers should fully understand the professional training objectives, combined with students choose English teaching materials, different professional use of different public English teaching materials, distinguish, select the teaching content, and strive to achieve common class is not common. Second, English teachers should selectively use English teaching materials, focusing on the development of one or several aspects, to strengthen the students' English vocational skills. Such as secretarial and other liberal arts students and similar to the electrical and other science and engineering students, in the future of professional positions, the application of English requirements are different. The former focuses on the strong English listening, speaking and writing skills, while the latter requires good at English reading and translation. Finally, the public English teachers can follow the principles of English for the employment services, targeted to prepare with the characteristics of the school's public English teaching materials and supporting teaching materials. Self-compiled textbooks should strive to include the professional used in the most commonly used, the most common English knowledge, teachers have plans to stage the professional knowledge of professional knowledge, and with the appropriate professional application skills training, so that students graduate, , Reading, writing, translation and other application capabilities have a certain level of improvement, to the beginning of employment when you can use English to deal with the level of foreign basic business.

Public English teaching precedes professional English teaching. Public English teaching is the first in the professional teaching, has played the beginning, high school English knowledge, convergence of professional learning role, cultivate students to further study the ability of professional English knowledge to protect the smooth development of professional English teaching. Public English teaching must be arranged in the first and second year, to ensure that the State Council recommended the minimum hours of school hours, follow the "practical, enough for the degree" principle. It aims to improve the basic knowledge, improve the comprehensive application 
ability of listening, speaking, writing and translation, and lay a good foundation for the professional English teaching in the second and third year. Try to use multimedia technology. This course is a lot of graphics, formulas, information capacity, and bilingual teaching requires a lot of professional English in the classroom, for students to understand the general situation of listening comprehension, teachers tend to use blackboard method to make up for some key difficult problems , Teachers need to repeat the explanation, etc., these are bound to affect the progress of teaching, but the teaching plan is to be completed, so the use of English textbooks bilingual classroom to be used in multimedia teaching to increase the amount of lecture information, improve teaching efficiency, otherwise It is difficult to complete the teaching tasks within the number of hours specified in the syllabus. In addition, most of the students in English reading ability is strong and weak ability to hear. The use of multimedia courseware can be fully described in the content on the big screen, so that students are teaching the general content at a glance, to facilitate students to understand and record, and will not become a professional lesson into a "listening class."

\section{Conclusion}

How to cultivate college students' English practical ability is an important system of personnel training in college English teaching. It needs to combine the college English teaching practice to grasp the overall requirements of English courses, and take into account the correct understanding of university orientation, on the basis of the development of a guiding significance of the new syllabus, so as to guide teachers to use a variety of diversity and all-round The form of teaching gradually implemented in English teaching practice. It is hoped that employment-oriented new model of college English teaching will be realized in our school at an early date. Because it is not only the medical college students in the English language test and enhance the employment competitiveness of the opportunity, but also the school English teachers themselves development opportunities and challenges.

\section{References}

[1] Liang Yibin, Bai Jingyong. Study on the Curriculum System of English Majors in Higher Vocational Education Guided by Industry Standard [J]. Vocational and Technical Education, 2010 (32)

[2] Tian Yan. The Higher Vocational English Curriculum Assessment [J]. Commercial Economics, 2009 (24)

[3] Li Yang, Zhang Tiejun. Application and exploration of ability-based education in higher vocational English teaching [J]. Journal of Harbin Institute of Finance, 2009 (04)

[4] Zou Yan. Study on the Strategies of Public English Teaching in Higher Vocational Colleges Based on Students' Needs [J] .New West, 2009 (08)

[5] Jiang Xiaoling. Study on improving the efficiency of English teaching in vocational schools [J]. Journal of Ningbo Polytechnic, 2009 (04)

[6] Luo Dongshan. Based on the employment orientation of vocational English teaching characteristics [J]. Vocational Education Research, 2009 (04) 